\title{
The management of change in the information age: Approaches of academic library directors in the USA
}

\section{Zhixian Yi}

\begin{abstract}
This study examined the approaches that academic library directors use to manage change using Bolman and Deal's reframing change model as a guide. In addition, a regression analysis was conducted to study the influences of demographics, library characteristics and human capital variables on the approaches used. Data were collected from an online survey and descriptive and inferential statistics were used to analyze the collected data. The findings reveal that the frame-related issues in academic libraries and director managerial actions coincided with and confirmed the Bolman and Deal model. Results demonstrate that directors actually used multiple approaches as well as single and dual approaches to manage change. Demographic variables such as age and library characteristics such as library type and library size were significant predictors of the approaches used, but this study indicates that human capital variables and number of library branches made no difference. The results are helpful to better understand directors' attitudes and behaviours, and the factors that influence approaches to change management.
\end{abstract}

\section{Introduction}

The information age has enhanced the nature of change. With the rapid development of information technology and the wide applications of social media tools, change in academic library settings now occurs more quickly and is more unpredictable. As Moran, Stueart and Morner $(2013,1)$ stated, "All organizations have been affected by changes brought about by information technology, but few have been so transformed as libraries and information centers."

\section{Author \\ Zhixian (George) Yi is a lecturer in the School of Information Studies at Charles Sturt University, Wagga Wagga, NSW, Australia. \\ Email: gyi@csu.edu.au}


Rapid changes in information technology affect all areas of academic libraries, from acquisitions to cataloguing, research, and online learning. Ready information is now at everyone's fingertips: internet information is so widespread, it has created an increased demand for prompt and responsive information service (Warnken, 2004); patterns of scholarly and publication communication have changed; and many colleges and universities now offer long-distance education (Association of Research Libraries, 1996). To ensure that libraries run smoothly and meet the current needs of all students, faculty, and staff, directors must learn to successfully manage constant and evolving change. However, little is known about the approaches that directors actually use to manage change, and the factors that may influence their choice of approach used.

The research aim of this study was to examine the approaches that academic library directors used to manage change using Bolman and Deal's reframing change model as a guide. In addition, a regression analysis was conducted to study the influences of demographics, library characteristics and human capital variables on the approaches used. This study addresses two research questions:

- How do directors of academic libraries report the way they manage change?

- What factors influence their approaches to managing change?

The value of this study exists in linking theory to action using the reframing change model to examine the approaches used, and confirming that the important change management tools are structural, human resource, political, symbolic, dual and multiple approaches. The results are helpful to better understand directors' attitudes and behaviors, and the factors that influence their approaches to change management. The value of knowing how change is being managed lies in providing people with new knowledge and enabling people to gain a greater appreciation of directors' approaches used, and to manage change better in the future.

\section{Literature review}

\subsection{The Bolman and Deal reframing change model}

This study concentrates on Bolman and Deal's reframing change model (1984, 1991a, 1991b, 1997, 1999, 2003, 2008), which views change from structural, human resource, political, and symbolic perspectives. Bolman and Deal developed their four-frame model by first reviewing the literature, and then confirmed their model through empirical studies.

According to Bolman and Deal (1991a, 323), managing change from a structural perspective is to communicate and realign formal roles and relationships to reduce confusion and unpredictability; a human resource perspective is to provide training and support for people who feel incompetent, needy, and powerless because of change; a political perspective encompasses dealing with conflict and forming new coalitions; and a symbolic perspective is to create rituals. While managing change, leaders and managers may use one (single), two (dual), or three or more (multiple) of these approaches. However, no empirical study has been 
conducted to examine these specific approaches within the library setting (Bolman and Deal, 1991a, 323). This study fills this gap.

\subsection{Managing change through structural, human resource, political, symbolic or multiple approaches}

The literature describing empirical studies of the four approaches used within academic libraries is scarce. Examples of each approach are described below.

\subsubsection{Structural approach}

Documented empirical studies of the structural approach used to manage change date back to the 1990s (Bowers, DeBeau-Melting, DeVries and Schellinger, 1996; Duchin, 1997, 141; Harris and Marshall, 1998; Kingsley, 1997, 145; Stanley and Branche-Brown, 1995, 424). These studies described how organizational goals were met when authorities managed change and resolved conflicts within technical services divisions, functional organizational structures, and even entire academic library systems.

In 1995, Stanley and Branche-Brown described the reorganization of the technical services division at the Pennsylvania State University (State College) libraries. The reorganization, which resulted in self-directed work teams, represented a major cultural change for the library system. According to Stanley and BrancheBrown $(1995,424)$, training and empowerment were the key elements of effective team work. "The success of each decision is directly related to the individuals involved" (Stanley and Branche-Brown, 1995, 424). Unfortunately, the study did not collect demographic and human capital data that might have influenced participants' approaches to making correct change decisions.

\subsubsection{Human resource approach}

People are the most important variable to be taken into account during change. A few sources (Hawthorne, 2004; von Dran, 2005; Webb, 1989) described the human resource perspective within the library setting. Hawthorne (2004, 185), Director of Library Human Resources at the University of California at Los Angeles (UCLA), acknowledged that every library must adequately cope with change in order to meet current needs. She highlighted the need for proactive management of change in libraries and the integration of human resource management and organizational development (Hawthorne, 2004, 185). Von Dran $(2005,183)$ stresses that leaders and managers of change must understand their own capacity for change and their resilience in coping with inevitable stresses. Webb cautioned that libraries should address:

the challenges faced by information services, the need to reallocate, reclassify, and retain existing staff, and the increasingly important role human resource specialists play in libraries in transition.

(Webb, 1989, 1-2) 


\subsubsection{Political approach}

When dealing with change, political power is an important element worth considering (Atkinson, 1990, 98). The political approach can be used on several levels. First, change agents at various levels of the library staff have different roles and responsibilities for managing change. If a manager does not have the primary responsibilities for change, he or she may need to turn to a more senior level of management, which may possibly be the board, the city manager, or a vice president. This may be frustrating and possibly may seem futile (Curzon, 2005, 106). Second, academic libraries depend on their parent institutions, and political realities, albeit frustrating, should be taken into account at all times while managing change (Curzon, 2005, 106; Gallacher, 2000, 16). The resultant frustration and change may cause conflicts. If handled well, the political perspective can create arenas where issues can be negotiated rather than being driven underground (Bolman and Deal, 1991, 377).

\subsubsection{Symbolic approach}

Managing change from a symbolic perspective is widely explored in many fields, but to a much lesser degree in academic library science. Most of the literature on symbolic change in libraries is presented in opinion papers; there are few related empirical studies. Different metaphors were used while "restructuring, realigning, and repackaging today's research libraries" (Giesecke, 2011, 54).

Patkus and Rapple (2000, 199), librarians at Boston College, noted that core values provide a common vision for employees. As librarians seek to deal with constant change, the identification and adoption of fixed and unchanging core values may be the ideal strategy to embrace change successfully (Patkus and Rapple, 2000, 203).

To back up their beliefs, the authors further described their personal experiences at Boston College library system. As part of a reorganisation started in 1994, external consultants were hired to lead the staff through the change process. The reorganization was assessed within the first year and then again three years later. Reassessment reports, which focused on several key areas, including values, people and skills, and communication, were reviewed by employees across the system. During this process, core values were identified as the glue that held everything together (Patkus and Rapple, 2000, 202).

\subsubsection{Multiple approaches}

It is very important for leaders and managers to view a situation using a multiframe approach while managing strategically (Linn, 2008, 124). Few empirical studies on the multiple perspectives within the academic library setting have been done in the United States (Bowers et al., 1996; Nozero and Vaughan, 2000). The case study by Bowers et al. $(1996,133)$ demonstrates multiple perspectives of change management at the University of Minnesota libraries. The entire library system changed from a structural to a cultural perspective by creating task forces, building a team and communication, defining personal and institutional values, 
and developing skills of team members. As described previously, Nozero and Vaughan (2000) examined the planning and implementation of change from multiple perspectives, including the symbolic approach, at the University of Nevada, Las Vegas. The researchers analyzed the two seemingly divergent methods used: (1) re-engineering or a radical change approach and (2) process improvement or slow incremental change. The library system was successful in using polar opposite methods of change because top management was open to change and encouraged both change and communication with all staff members (Norezo and Vaughn, 2000, 420).

I have previously used Bolman and Deal's reframing change model to examine approaches to setting goals for change (Yi, 2013a), managing change in information technology ( $\mathrm{Yi}, 2009)$, planning change (Yi, 2011), conducting meetings in the change process (Yi, 2012), and evaluating change (Yi, 2013b). However, empirical studies are still lacking. Most empirical research focuses on practice, is cross-sectional, and relies on surveys and case studies for data. Today, there is an increasing need for academic libraries to perform change projects in response to external and internal pressures. Because academic library directors play a key role in managing change, there is a need for research on the approaches used to manage change and the impact that directors' demographic and human capital data have on choosing these approaches.

\section{Study framework and hypothesis development}

Using Bolman and Deal's reframing change model as a guide, this study explores the relationships between directors' various approaches used to manage change and three kinds of predictors: (1) demographics, (2) human capital, and (3) library variables. Demographics refer to age and gender. According to Frank and Bernanke (2007), human capital is:

an amalgam of factors such as education, experience, training, intelligence, energy, work habits, trustworthiness, and initiative that affect the value of a worker's marginal product.

(Bernanke, 2007)

In this study, human capital is composed of education level, years at present position, number of different positions, years of directorship, years of service, and number of subordinates. Library variables are composed of number of library branches, type, and size.

In the information age, the differences of the given time and situations may affect academic library directors' approaches to change management. Directors also have different demographics and human capital and their library features are not the same.

Davis (1996, v) discovered that "Women reported using all four managerial frames more often than men who reported using one or two frames more frequently." Females are hypothesized to be more likely than males to use multiple approaches to manage change. Older directors have rich experience in 
managing change, and are therefore hypothesized to be more likely than younger ones to use the multi-frame approach when managing change.

It is hypothesized that directors in the following situations are more likely than their counterparts to use the multi-frame approach than any other type of approach when managing change in the information age:

H1. Directors with a higher level of education possibly have acquired knowledge of different approaches.

H2.Directors who have been in their current positions, directorship, or service for longer periods of time may build on rich past experiences and may have dealt with and thought about many issues, including "structure, needs, conflict, and loss" (Bolman and Deal, 2003), when managing change.

H3. Directors who have held several different positions are more likely to have experienced more changes, thought about more issues, and used different types of approaches.

H4.Directors who oversee more subordinates and locations may have experienced and managed more changes in the information age. Directors who supervise more subordinates may have experienced more alignments of roles and responsibilities and interpersonal interactions.

H5.Directors with more enrollments are more likely to have experienced and managed more changes (Euster, 1987, 79).

H6.Directors who work for an institution offering a higher academic degree may have experienced more library-wide reorganizations (Association of Research Libraries, 1996).

The questions addressed by the research include how directors report the way they manage change and what factors influence their approaches to managing change. One of the purposes of this study is to test the above hypotheses through the use of binary and multinomial logistic regressions.

\section{Methodology}

\subsection{Population and sample}

There were 1,591 American colleges and universities according to the 2008 Higher Education Directory (Burke, 2008, xlix). In the pilot and large-scale studies, 1,028 academic library directors with complete names and email addresses available from the American Library Directory 2007-2008 (2007) and from library websites were cordially invited to complete online surveys via the website surveymonkey.com. During the study, all of them worked and lived in the United States.

A questionnaire for the large-scale study was revised based on feedback received from 18 random respondents during a pilot study. The remaining 1,010 directors were sent a revised survey via email to complete and return within 15 days in 2009. In order to obtain more responses, they were also sent reminder emails. All 
respondents' participation was strictly voluntary. The number of directors who completed and returned surveys was 596 (59\%).

\subsection{Survey design}

The two sections of an online survey were: (1) personal and organizational information and (2) quick-response questions with multiple choices and free comments.

In the first section, survey questions focused on three kinds of predictors:

1. demographics (gender and age of directors);

2. human capital (education level, years at present position, years of directorship, years of service, number of different positions, and number of subordinates);

3. library variables (number of library branches, type, and size).

Most of the multiple choices for quick-response questions in the second section were based on Bolman and Deal's reframing change model. One of the main survey questions asked how directors managed change. The choices for the approaches used to manage change were:

1. communicate and realign formal roles and relationships to reduce confusion and unpredictability;

2. provide training and support for people who feel incompetent, needy, and powerless because of change;

3. deal with conflict and form new coalitions;

4. create rituals;

5. other approaches.

Yes, no, or N/A (not applicable) for each response were provided for each respondent to choose. For the "other" option, directors could write their free comments on the approaches used.

\subsection{Variables and measurements}

A dependent variable is a variable whose value is determined by the values assumed by other variables in the relation. In this study, the dependent variables related to the perspectives on managing change described above; structural, human resource, political, symbolic, dual, multiple, and other. In terms of this survey question: how directors managed change, respondents choosing response one were identified as structural approach directors; response two classified as human resource approach directors and so on. Single-approach directors were those who chose only one of the five responses, and dual-approach directors were those who chose any two responses. Those who chose three or more affirmative responses were identified as multi-frame approach directors. Dependent variables were nominal ones. 
An independent variable is a variable whose value determines the value of other variables. Demographics, human capital, and library variables were considered the independent variables for this study.

\subsection{Data analysis and analytical strategies}

Descriptive content analysis (Sarantakos, 2005, 300) was used to analyze the data collected from open-ended responses to how directors managed change. Bolman and Deal's $(1991 b, 515)$ criteria for coding frame responses were the bases to code the qualitative data. Data were coded based on whether they matched the corresponding Bolman and Deal categories. Those matching the categories were coded as the structural, human resource, political, or symbolic approach.

A general category or "other" approach was assigned to data that did not match the categories. In terms of themes and patterns, the "other" approach was divided into subcategories. Qualitative data analysis (Dalziel, 2007, 47) was used to code, group, and reclassify the response categories for the "other" approach according to respondents' free comments.

The main methods of analysis were multinomial and binary logistic regression. Multinomial logistic regression describes the relationship between a dependent variable and a set of predictor variables. Binary logistic regression is a type of regression analysis where the dependent variable is a dummy variable. As verified by Trieman (2009), multinomial logistic regression was most appropriate for this study for the following reasons:

1. Dependent variables of this study are "categorical variables with more than two categories" (Treiman 2009, 335);

2. The procedure of multinomial logistic regression "involves simultaneously estimating a set of logistic regression equations" (Treiman 2009, 336);

3. One category of the dependent variable can become the reference category, and:

The estimation procedure yields, for a set of ... categories for some dependent variable, ... logistic regression equations, each of which predicts the log odds of a case falling into a specific category rather than the reference category...

(Treiman 2009, 336)

Frequencies and other descriptive statistical methods were first used to look at the distribution patterns of the individual variables. Then, multinomial and binary logistic regressions were conducted. This analysis developed a full regression model with all independent variables included to determine the factors influencing the approaches used by directors.

\subsection{Limitations of the study}

The study was dependent upon the willingness and ability of academic library directors to respond accurately to the survey questions. Academic library directors' views about how to manage change might be different from the views 
of independent observers. Data were collected in 2009 and only from directors giving their approaches used to manage change for only one point in time.

Researcher subjectivity in coding responses to open ended questions might exist. Accordingly, the results of the study might lack generalisability. Misinterpretation of the survey questions and personal bias might result in inaccurate responses.

\section{Results}

In the large-scale study, $76.3 \%$ (455) of 596 respondents returning the surveys successfully answered the question on the approaches used to manage change. The final analysis did not include 11 questionnaires from respondents who did not hold the job title of directorship, deanship, or equivalent, and the 130 incomplete questionnaires.

\subsection{Descriptive results}

As shown in Table 1 below, only $9.0 \%$ of directors used single approaches, while multiple approaches were utilised by $75.8 \%$ of all respondents. Only $15.2 \%$ employed dual approaches. N/A (not applicable) was not checked by any respondent. However, single symbolic, political, or other approach to managing change was not employed by any director.

The "other" approach option was selected by 4.2\% (19) of respondents. Among these, 12 made free comments on the "other" approach used. However, according to the Bolman and Deal's model, no comment reflected a true "other" approach used. Actually, four responses were the human resource approach; three, symbolic; three, dual approaches; and two, comments. The remaining 7 directors only checked "other" and did not provide further details of the approaches used. Therefore, the final analysis included 7 directors in the "other approach" category in Table 1.

Respondents' free comments focused on empowering staff, creating social rituals, and dealing with conflicts in the change process. The human resource, symbolic, and dual approaches were used more than other approaches.

In terms of the dual or multiple approaches, the structural and human resource approaches appeared together more often than the others. This might be because in changing environments, directors focus their work on people, and frequently realign roles and duties of staff.

\subsection{Dependent variables}

The dependent variables were analyzed using descriptive statistics. As displayed in Table 1, the dependent variables were the directors' approaches used to manage change. Single approaches, dual approaches, and multiple approaches were the three main categories of the dependent variable. Two subcategories of the single approaches were structural and human resource approaches. 


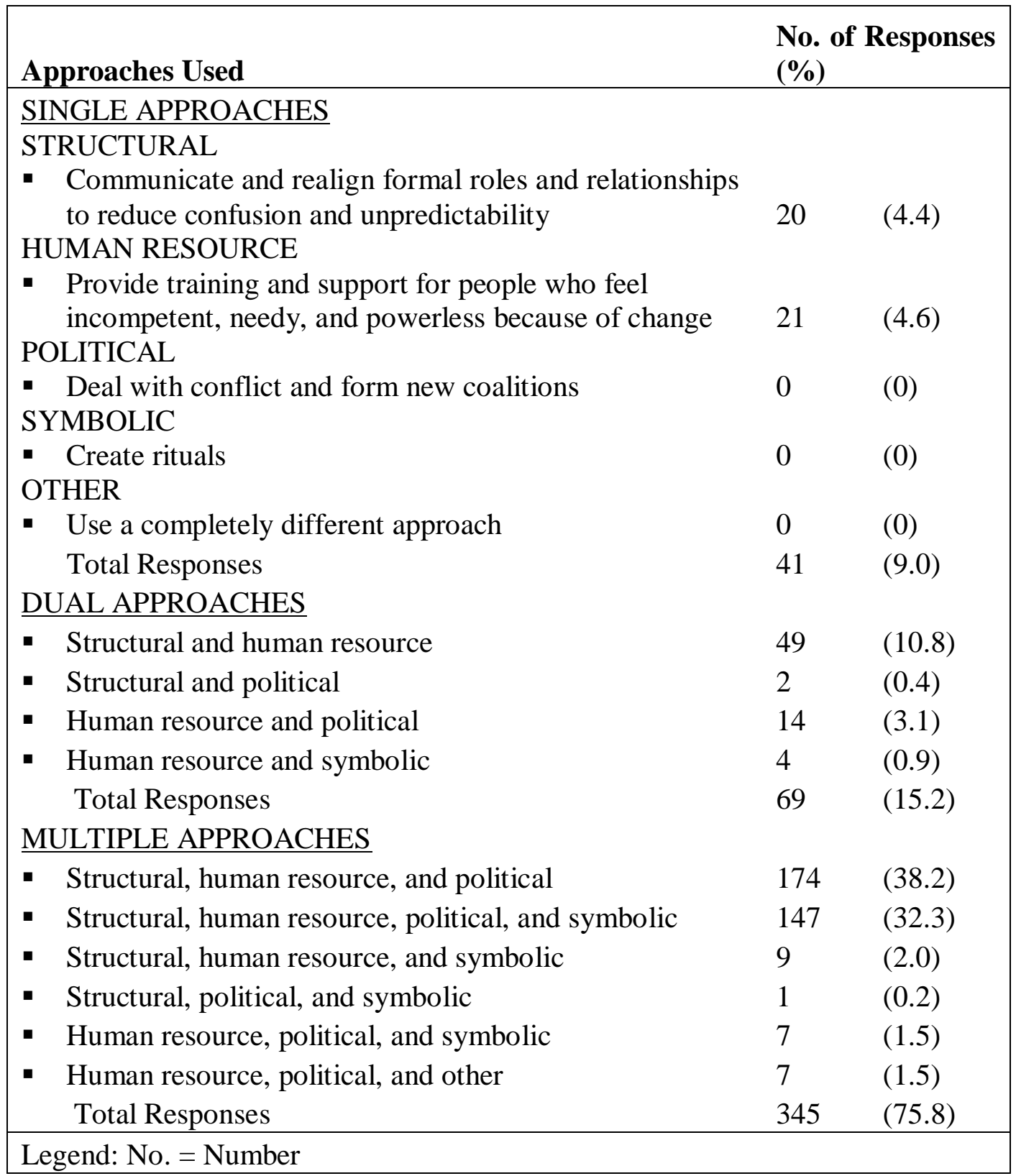

Table 1: Approaches used to manage change in the information age $(\mathrm{N}=$ 455).

\subsection{Independent variables}

Table 2 shows the statistical results of the independent variables used in the analysis. Gender and library type were nominal variables. An ordinal variable is a categorical one with observations logically ordered or ranked. The ordinal variables included age, education level, the number of subordinates, and library size. A continuous variable is a numeric one. The other independent variables were continuous ones. 
Age comprised nine categories (25-29 years, 30-34 years, and on up to > 65 years). Education consisted of six levels from bachelor's degree to doctorate. The number of subordinates was originally a continuous variable. It was finally recoded to four categories because the correlation between the number of subordinates and the number of library branches was detected to be high ( $\mathrm{r}=$ .716), which might indicate a potential multicollinearity problem (two or more predictor variables being highly correlated). Library type was classified according to the Carnegie classifications, and the library size was categorized based on the number of student enrollment.

\begin{tabular}{|lcc|}
\hline Variables & Percent/Mean & SD \\
\hline Male & $44.2 \%$ & --- \\
Age (9-point scale) & $7.0^{\mathrm{a}}$ & $8.0^{\mathrm{b}}$ \\
Education level (6-point scale) & $4.0^{\mathrm{a}}$ & $5.0^{\mathrm{b}}$ \\
Years of present position & 8.7 & 7.9 \\
Years of all directorship, & & \\
$\quad$ deanship, or equivalent & 12.1 & 9.3 \\
Years involved in all library & 26.6 & 9.8 \\
services & & \\
Number of different library & 4.8 & 2.7 \\
$\quad$ professional positions & $2.0^{\mathrm{a}}$ & $3.0^{\mathrm{b}}$ \\
Number of subordinates & 1.6 & 3.4 \\
$\quad$ (4-point scale) & $2.0^{\mathrm{a}}$ & $2.0^{\mathrm{b}}$ \\
$\quad \begin{array}{l}\text { Number of library branches } \\
\text { Library type (3-point scale) }\end{array}$ & $1.0^{\mathrm{a}}$ & $3.0^{\mathrm{b}}$ \\
Library size (4-point scale) & \\
\hline Legend: SD = Standard deviation; ${ }^{\mathrm{a}}$ Median; ${ }^{\mathrm{b}}$ Range & \\
\hline
\end{tabular}

Table 2: Descriptive statistics of independent variables used in the analysis $(\mathrm{N}=455)$.

\subsection{Results of multinomial and binary logistic regressions}

'Single approaches' was the reference category because directors' use of multiple approaches versus single approaches was the focus of this study. The multinomial logistic regression estimates predicting directors' approaches used to manage change are reported in Table 3 . The estimated pseudo $\mathrm{R}^{2}$ (which refers to the square of the correlation of the model-implied and observed outcome value for all respondents) showed that $10.6 \%$ of the variations in the directors' approaches used were explained by this set of variables / subscales. According to the results, age and library type significantly influenced directors' approaches used.

The asterisks in Table 3 indicate the significance level of these results, with a single asterisk marking results significant to the 0.10 level (meaning the probability of the value occurring by chance was less than or equal to $10 \%$ ), a 
double asterisk marking results significant to the 0.05 level (meaning the probability of the value occurring by chance was less than or equal to $5 \%$ ), a triple asterisk marking results significant to the 0.01 level (meaning the probability of the value occurring by chance was less than or equal $1 \%$ ), and a four-asterisk marking results significant to the 0.001 level (meaning the probability of the value occurring by chance was less than or equal to $0.1 \%$ ).

The relationship between age and the use of single approaches versus multiple approaches was detected to be positive and significant. Each additional level in age increased the likelihood of using multiple approaches by $30.6 \%$. Older directors were more likely than younger ones to use multiple approaches. This is consistent with the hypothesis that older directors are more likely than younger ones to use the multi-frame approach while managing change.

Library type was detected to be positively and significantly related to the use of single approaches versus dual approaches. Directors who worked for a higher academic degree college or university were roughly twice as likely as their counterparts to use dual approaches to manage change.

There was a positive and highly significant relationship between library type and the use of single approaches versus multiple approaches. Directors who worked for a higher academic degree college or university were about 2.7 times as likely as their counterparts to use multiple approaches rather than single approaches. This supports the hypothesis that directors who work for a higher academic degree college or university are more likely than their counterparts to use the multi-frame approach to manage change.

In addition, the gender variable 'male' was detected to be marginally significantly (significance level close to .10) related to the use of dual approaches. The relationship between male and the use of multiple approaches, and the relationship between the total years of directorship and the directors' use of multiple approaches were also detected to be marginally significant (significance near .10). However, the other variables might not make any difference (significance far from $.01)$.

In order to examine whether the results would change, a binary logistic regression analysis was conducted. Binary logistic regression is a kind of regression analysis where the dependent variable is not continuous but instead has only two possible outcomes, 1 or 0 . As reported in Table $4,11.5 \%$ of the variations in the directors' approaches to change management were explained by this set of variables / subscales. According to the results, age and library type still significantly influenced the approaches used. 


\begin{tabular}{|c|c|c|c|c|}
\hline \multirow[b]{2}{*}{ Predictors } & \multicolumn{2}{|c|}{$\begin{array}{c}\text { Dual approaches } \\
\text { vs. } \\
\text { Single approaches }\end{array}$} & \multicolumn{2}{|c|}{$\begin{array}{c}\text { Multiple approaches } \\
\text { vs. } \\
\text { Single approaches }\end{array}$} \\
\hline & $\beta$ & $\exp (\beta)$ & $\beta$ & $\exp (\beta)$ \\
\hline Male & $\begin{array}{l}.658 \\
(.437)\end{array}$ & 1.931 & $\begin{array}{l}.564 \\
(.380)\end{array}$ & 1.757 \\
\hline Age & $\begin{array}{l}.153 \\
(.169)\end{array}$ & 1.165 & $\begin{array}{l}.267 * * \\
(.141)\end{array}$ & 1.306 \\
\hline Education level & $\begin{array}{l}-.015 \\
(.193)\end{array}$ & .985 & $\begin{array}{l}-.129 \\
(.166)\end{array}$ & .879 \\
\hline Years of present position & $\begin{array}{l}-.025 \\
(.033)\end{array}$ & .976 & $\begin{array}{l}-.016 \\
(.029)\end{array}$ & .984 \\
\hline Total years of directorship & $\begin{array}{l}-.019 \\
(.033)\end{array}$ & .981 & $\begin{array}{l}-.043 \\
(.029)\end{array}$ & .958 \\
\hline $\begin{array}{l}\text { Total years of } \\
\text { library service }\end{array}$ & $\begin{array}{l}.032 \\
(.031)\end{array}$ & 1.033 & $\begin{array}{l}.017 \\
(.026)\end{array}$ & 1.017 \\
\hline $\begin{array}{l}\text { No. of different } \\
\text { positions }\end{array}$ & $\begin{array}{l}-.073 \\
(.093)\end{array}$ & .930 & $\begin{array}{l}-.008 \\
(.071)\end{array}$ & .992 \\
\hline $\begin{array}{l}\text { No. of } \\
\quad \text { subordinates }\end{array}$ & $\begin{array}{l}.051 \\
(.203)\end{array}$ & 1.052 & $\begin{array}{l}.086 \\
(.174)\end{array}$ & 1.090 \\
\hline $\begin{array}{l}\text { No. of library } \\
\text { branches }\end{array}$ & $\begin{array}{l}-.047 \\
(.091)\end{array}$ & .954 & $\begin{array}{l}-.005 \\
(.067)\end{array}$ & .995 \\
\hline Library type & $\begin{array}{l}.690 * * \\
(.341)\end{array}$ & 1.993 & $\begin{array}{l}.981 * * * * \\
(.295)\end{array}$ & 2.668 \\
\hline Library size & $\begin{array}{l}-.275 \\
(.333)\end{array}$ & .760 & $\begin{array}{l}-.236 \\
(.280)\end{array}$ & .790 \\
\hline Constant & $\begin{array}{l}-1.635 \\
(1.064)\end{array}$ & & $\begin{array}{l}-746 \\
(.888)\end{array}$ & \\
\hline-2 log likelihood & & 610.6 & & \\
\hline Model $\chi^{2}$ & & 38.0 & & \\
\hline Pseudo $\mathrm{R}^{2}$ & & .106 & & \\
\hline Df & & 22 & & \\
\hline $\mathrm{N}$ & & 455 & & \\
\hline
\end{tabular}

Table 3: Multinomial logistic regression estimates predicting approaches to managing change $(\mathrm{N}=455)$. 


\begin{tabular}{|c|c|c|}
\hline \multirow[b]{2}{*}{ Predictors } & \multicolumn{2}{|c|}{ Itiple approaches vs single approaches } \\
\hline & $\beta$ & $\exp (\beta)$ \\
\hline Male & $\begin{array}{l}.563 \\
(.375)\end{array}$ & 1.756 \\
\hline Age & $\begin{array}{l}.278 * * \\
(.140)\end{array}$ & 1.321 \\
\hline Education level & $\begin{array}{l}-.088 \\
(.162)\end{array}$ & .915 \\
\hline Years of present position & $\begin{array}{l}-.021 \\
(.028)\end{array}$ & .979 \\
\hline Total years of directorship & $\begin{array}{l}-.036 \\
(.028)\end{array}$ & .965 \\
\hline Total years of library service & $\begin{array}{l}.013 \\
(.025)\end{array}$ & 1.013 \\
\hline No. of different positions & $\begin{array}{l}-.015 \\
(.070)\end{array}$ & .985 \\
\hline No. of subordinates & $\begin{array}{l}.032 \\
(.169)\end{array}$ & 1.033 \\
\hline No. of library branches & $\begin{array}{l}-.007 \\
(.059)\end{array}$ & .993 \\
\hline Library type & $\begin{array}{l}.907 * * * \\
(.289)\end{array}$ & 2.477 \\
\hline Library size & $\begin{array}{l}-.350 \\
(.259)\end{array}$ & .704 \\
\hline Constant & $\begin{array}{l}-.281 \\
(.863)\end{array}$ & .755 \\
\hline$-2 \log$ likelihood & & 251.0 \\
\hline Model $\chi^{2}$ & & 24.5 \\
\hline Pseudo $\mathrm{R}^{2}$ & & .115 \\
\hline Df & & 11 \\
\hline $\mathrm{N}$ & & 455 \\
\hline
\end{tabular}

Table 4: Binary logistic regression estimates predicting approaches to managing change $(N=455)$.

As indicated in Table 1, the human resource approach was used more often than any other single approach. Thus, it was used as a reference category for a further multinomial logistic regression analysis. The results are reported in Table 5. The estimated pseudo $\mathrm{R}^{2}$ shows that $12.3 \%$ of the variations of the directors' approaches used to manage change were explained by this set of variables / 
subscales. According to the results, the independent variables that significantly influenced the approaches used were gender, library type, and library size.

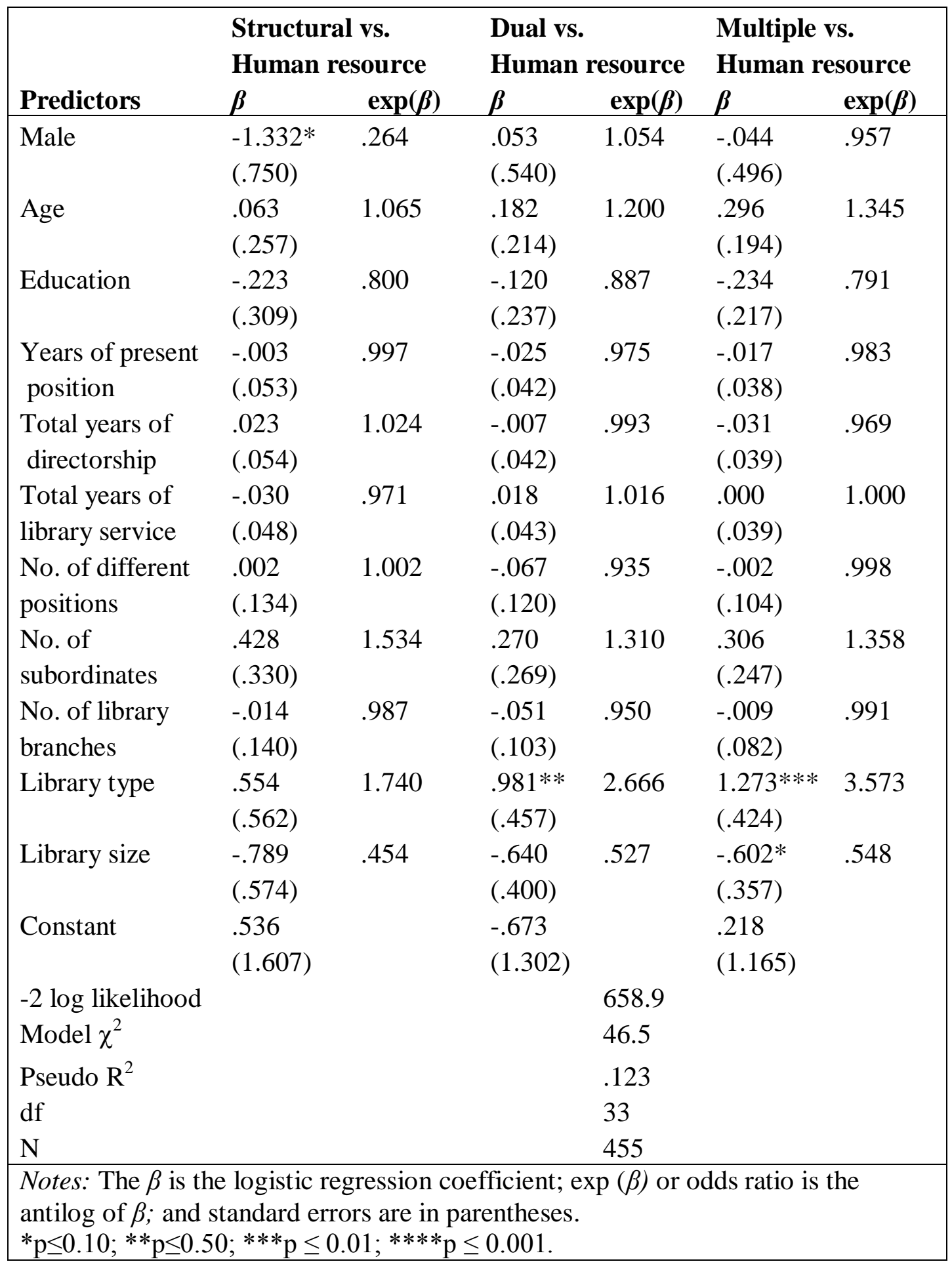

Table 5: Multinomial logistic regression estimates predicting approaches to managing change $(N=455)$. 
The relationship between gender and the use of the human resource approach versus structural approach was detected to be negative and significant. Males were about $74 \%$ less likely than females to use the structural approach rather than human resource approach.

There was a positive and significant relationship between library type and the use of the human resource approach versus dual approaches. Directors who worked for a higher academic degree college or university were about 2.7 times as likely as their counterparts to use dual approaches to manage change. Library type was found to be positively and very significantly related to the use of the human resource approach versus multiple approaches. Directors who worked for a higher academic degree college or university were about 3.6 times as likely as their counterparts to use multiple approaches rather than single approaches to mange change. This is consistent with the hypothesis that directors who work for a higher academic degree college or university are more likely than their counterparts to use the multi-frame approach while managing change.

Library size was detected to be negatively and significantly related to the use of the human resource approach versus multiple approaches. Each additional level in library size decreased the likelihood of using multiple approaches by $45.2 \%$. Those who worked for a college or university with higher enrollment were less likely than their counterparts to use multiple approaches. This rejects the hypothesis that directors with more enrollments are more likely than their counterparts to use the multi-frame approach.

In addition, the relationship between age and the use of the human resource approach versus multiple approaches was found to be marginally significant (significance close to .10). However, the other variables did not make any significant difference.

\section{Discussion}

This study has confirmed that change is generally managed in academic libraries from structural, human resource, political, symbolic, dual, or multiple perspectives. Most directors used multiple approaches to manage change.

In practice, it is common to use more than one approach to manage change because the "messy, turbulent world rarely presents us with well-defined, singleframe problems" (Bolman and Deal, 2003, 301).

Academic libraries face multiple and evolving changes, and every event is open to new interpretations. Before reframing can occur, directors must first honestly look at the approaches being used and those being ignored. The next step is to critically evaluate the success of the current approach(es). Bolman and Deal (1984, 245246) term this action breaking out of our "psychic prisons". Critical selfassessment and reframing will allow new questions to arise and new options for action.

Reframing can clarify a situation, generate options, and evaluate strategies in addition to better understanding the multiple realities of coworkers. When 
someone's behavior is puzzling, most likely they see the world through different lenses. Using the reframing approach, directors, managers, and librarians can learn to integrate different approaches to managing change and better understand each other. As Bolman and Deal observe:

the turbulent managerial world of the next few decades will belong to the managers and the organizations with a more comprehensive understanding of the phenomena of each of the four frames.

(Bolman and Deal, 1984, 278-279)

The results of this study allow a better understanding of directors' attitudes, behaviors, and approaches used to manage change in academic libraries. Directors may use these results to reflect on various choices of management strategies and to balance the weight of these influences. Questions to consider include:

1. What approaches should I consider if large-scale change projects are to be undertaken?

2. What demographic characteristics do I have?

3. What are the characteristics of our library?

4. Based on a comprehensive analysis of the current situation, what approach is most appropriate to use?

While managing change, directors need to have a good understanding of their own demographic characteristics. In general, this will give them a better idea of what approaches they would be most likely to gravitate towards in a given situation. Reviewing the characteristics of the situation and their favoured approaches will help the directors adjust managerial behaviors to meet the needs of the situation.

The findings of this study will help directors analyse the characteristics of their libraries, reflect on different management approaches, and balance the weight of factors that significantly influence the approaches used, as shown by both quantitative and qualitative data analyses.

The main finding of this study is that library variables played an important role in the approaches used. While reflecting on the approaches used, directors should clearly understand their own library features and consider the most appropriate approaches. Directors need to look at a specific change issue or problem using each of the confirmed approaches, reframe one more time, and finally determine which approach is the most appropriate. The management approaches chosen depend on the situation. As the situation evolves, so should the approaches used.

If librarians are provided with the directors' approaches used to manage change, and students of library and information science are educated in these approaches and how to appropriately use them, they will have a better understanding of change management. This knowledge will enable them to understand different management techniques and enhance their communication skills by developing empathy for the viewpoints of their coworkers. Classes on change management 
should be given in graduate school, and library directors may provide workshops for their librarians.

\section{Conclusion}

This study contributes to the body of knowledge relating to change management in the academic library, as well as the professional management and leadership literature, by examining how directors actually manage change and the factors influencing the management approaches used.

When managing change, directors were found to use multiple approaches as well as single and dual approaches. Demographic variables such as age, and library characteristics such as library type and library size were significant predictors of the approaches used, but this study indicates that human capital variables and number of library branches made no difference.

The findings of this study help to explain some management behaviors and how they affect the academic library setting. This study has illustrated that framerelated issues in academic libraries and director managerial actions coincided with and confirmed the Bolman and Deal model. This study has also demonstrated that directors use multiple approaches as well as single and dual approaches to manage change, and provided examples of how directors' demographics, and library characteristics relate to the use of structural, human resource, political, symbolic, dual, and multiple approaches. Directors, managers, and librarians can benefit from knowing how demographics, and library characteristics influenced directors' approaches. For example, directors might reflect on how they generally manage change through communicating and realigning formal roles and relationships, providing training and support for people, dealing with conflict, and creating rituals as respectively seen in the structural, human resource, political and symbolic approaches.

To manage any large-scale change in resources or services, directors and librarians need to automatically reframe their approaches to the given time and situation. During the course of change, approaches may need to be reframed several times to meet evolving needs. How to select and use appropriate approaches may be taught in schools as well as in work places. Schools of library and information studies may offer courses relating to director approaches to better prepare students for their role as change leaders in the future, while libraries or professional associations of library and information science may provide related training programs and workshops for directors and librarians. According to Bolman and Deal $(2003,309)$, choosing a framework or understanding coworkers' perspectives requires intuition, analysis, and artistry.

Currently, there is an increasing need for academic libraries to effectively manage change in response to external and internal pressures. However, managing change in the academic library setting can be difficult. Academic library directors are change leaders and play a key role in effectively managing change in academic libraries because change can be led, and leadership does make a difference (Fullan 2001, 34). The roles of academic library managers, librarians, and staff as change 
agents are the key to effective change management. This study confirmed that some directors managed change from a structural perspective, while others managed change from multi-frame perspectives. So, what are the reasons for the failures and what perspective leads to effectiveness? Future research should focus on determining the most effective approaches to managing change in today's academic library environment and the academic library director or manager attributes, leadership behaviors, and management styles that are associated with effective change management.

\section{References}

American Library Directory 2007-2008 (2007). $60^{\text {th }}$ ed. Medford: Information Today.

Association of Research Libraries (1996) Library reorganizations and restructuring (SPEC, Flier No. 215). Washington: Association of Research Libraries.

Atkinson, R. (1990) Preservation and collection development: Toward a political synthesis, The Journal of Academic Librarianship, 16(2), 98-103.

Bolman, L. G. and Deal, T. E. (1984) Modern Approaches to Understanding and Managing Organizations. San Francisco: Jossey-Bass.

Bolman, L. G. and Deal, T. E. (1991a) Reframing Organizations: Artistry, Choice, and Leadership. San Francisco: Jossey-Bass.

Bolman, L. G. and Deal, T. E. (1991b) Leadership and management effectiveness: A multi-frame, multi-sector analysis, Human Resource Management, 30(4), 509534.

Bolman, L. G. and Deal, T. E. (1997) Reframing Organizations: Artistry, Choice, and Leadership. $2^{\text {nd }}$ ed. San Francisco: Jossey-Bass.

Bolman, L. G. and Deal, T. E. (1999) 4 steps to keep change efforts heading in the right direction, The Journal for Quality and Participation, 22(3), 6-11.

Bolman, L. G. and Deal, T. E. (2003) Reframing Organizations: Artistry, Choice, and Leadership. $3^{\text {rd }}$ ed. San Francisco: Jossey-Bass.

Bolman, L. G. and Deal, T. E. (2008) Reframing Organizations: Artistry, Choice, and Leadership. $4^{\text {th }}$ ed. San Francisco: Jossey-Bass.

Bowers, M., DeBeau-Melting, L., DeVries, J. and Schellinger, M. (1996)

Organizational restructuring: A case study, Journal of Library Administration, 22(2/3), 133-144.

Burke, J. M. (2008) 2008 Higher Education Directory. Falls Church: Higher Education Publications. 
Curzon, S. C. (2005) Managing Change: A How-to-Do-it Manual for Librarians. New York: Neal-Schuman Publishers.

Dalziel, C. A. (2007) Factors that enhance nurses' use of health information systems to support clinical decision-making, [Master's thesis]. Victoria: Royal Roads University.

Davis, T. I. (1996) The ways administrators work: a study of the theoretical framers of leadership used by female and male secondary school principals in Pennsylvania. [PhD dissertation]. Philadelphia: Temple University.

Duchin, D. (1997) Moving right along: Changing in staffing, functions, workstation setup, and Personnel, Library Resources and Technical Services, 41(2), 139-142.

Euster, J. R. (1987) The Academic Library Director: Management Activities and Effectiveness. Westport: Greenwood Press.

Frank, R. H., and Bernanke, B. S. (2007) Principles of Microeconomics. $3^{\text {rd }}$ ed. New York: McGraw-Hill.

Fullan, M. (2001) Leading in a Culture of Change. San Francisco: Jossey-Bass.

Gallacher, C. A. (2000) Managing Change in Libraries and Information Services. London: Aslib.

Giesecke, J. (2011) Finding the right metaphor: Restructuring, realigning, and repackaging today's research libraries, Journal of Library Administration, 51(1), 54-65.

Harris, R. M. and Marshall, V. (1998) Reorganizing Canadian libraries: A giant step back from the front, Library Trends, 46(3), 564-580.

Hawthorne, P. (2004) Redesigning library human resources: Integrating human resources management and organizational development, Library Trends, 53(1), 172-186.

Kingsley, P. (1997) Change and decay, Library Resources and Technical Services, 41(2), 143-145.

Linn, M. (2008) Perspectives on managing a library, The Bottom Line: Managing Library Finances, 21(4), 124-128.

Moran, B. B., Stueart, R. D. and Morner, C. J. (2013) Library and Information Center Management. $6^{\text {th }}$ ed. Westport: Libraries Unlimited.

Nozero, V. A., and Vaughn, J. (2000) Utilization of process improvement to manage change in an academic library, Journal of Academic Librarianship, 26(6), 416-421.

Patkus, R. and Rapple, B. A. (2000) Changing the culture of libraries: The role of core values, Library Administration and Management, 14(4), 197-204.

Sarantakos, S. (2005) Social Research. $3^{\text {rd }}$ ed. New York: Palgrave Macmillan. 
Stanley, N. M. and Branche-Brown, L. (1995) Reorganizing acquisitions at the Pennsylvania State University libraries: From work units to teams, Library Acquisitions: Practice and Theory, 19(4), 417-425.

Treiman, D. J. (2009), Quantitative Data Analysis: Doing Social Research to Test Ideas. San Francisco: Jossey-Bass.

Von Dran, G. (2005) Human resources and leadership strategies for libraries in transition, Library Administration and Management, 19(4), 177-184.

Warnken, P. (2004) New technologies and constant change: Managing the process, Journal of Academic Librarianship, 30(4), 322-327.

Webb, G. M. (ed.) (1989) Human Resources Management in Libraries. New York: Haworth Press.

Yi, Z. (2009) The management of change in information technology: Approaches of academic library directors in the United States, The International Journal of Knowledge, Culture and Change Management, 9(11), 109-130.

Yi, Z. (2011) Planning change in the information age: Approaches of academic library directors in the United States, The International Journal of Knowledge, Culture and Change Management, 10(12), 155-176.

Yi, Z. (2012) Conducting meetings in the change process: Approaches of academic library directors in the United States, Library Management, 33(1/2), 2235 .

Yi, Z. (2013a) Setting goals for change in the information age: Approaches of academic library directors in the United States, Library Management, 34(3), 5-19.

Yi, Z. (2013b) The factors influencing American academic library directors' approaches to evaluating change in the information age, LIBRI: International Journal of Libraries and Information Services, 63(2), 98-107.

\section{Acknowledgements}

This study was supported by the 2009 Eugene Garfield Doctoral Dissertation Fellowship from Beta Phi Mu, the International Library and Information Studies Honour Society. Thanks to Profs. Keith Swigger, Philip Q. Yang, Robert Sidney Martin, Eileen McElrath, and JoAnn Danelo Barbour for their excellent guidance. 


\section{Open access and copyright}

Library and Information Research is an open access journal. A freely available copy of this paper may be downloaded from the journal's website: http://www.lirgjournal.org.uk.

Copyright and associated moral rights in works published in Library and Information Research are retained by the author(s) but this paper may be used freely, with proper attribution, in educational and other non-commercial settings. 